\title{
Serine/Threonine-Protein Phosphatase 6 Catalytic Subunit
}

National Cancer Institute

\section{Source}

National Cancer Institute. Serine/Threonine-Protein Phosphatase 6 Catalytic Subunit. NCI Thesaurus. Code C102903.

Serine/threonine-protein phosphatase 6 catalytic subunit (305 aa, $35 \mathrm{kDa}$ ) is encoded by the human PPP6C gene. This protein plays a role in protein dephosphorylation, cell cycle progression and receptor signaling. 